\title{
SPINAL CORD INJURY DUE TO DIVING ACCIDENTS AND STRESS AMONG ARTISANAL FISHERS ${ }^{1}$
}

\author{
Eliane Santos Cavalcante², João Mário Pessoa Júnior³, Izaura Luzia Silvério Freire, \\ Ana Cristina Mancussi e Faro ${ }^{5}$, Gilson de Vasconcelos Torres ${ }^{6}$, Francisco Arnoldo Nunes de Miranda ${ }^{7}$
}

\footnotetext{
${ }^{1}$ Article extracted from the dissertation - Life course of fishermen victim of spinal cord injury caused by diving: experiences, social representation and stress, presented to the Nursing Postgraduate Program of the Health Sciences Center, Universidade Federal do Rio Grande do Norte (UFRN), in 2014.

2 Ph.D. in Nursing. Professor, School of Health, UFRN. Natal, Rio Grande do Norte, Brazil. E-mail: elianeufrn@hotmail.com

${ }^{3}$ Ph.D. in Nursing. Professor, Universidade Federal do Rio de Janeiro. Macae, Rio de Janeiro, Brazil. E-mail: joaomariopessoa@gmail.com

${ }^{4}$ Ph.D. in Nursing. Professor, School of Health, UFRN. Natal, Rio Grande do Norte, Brazil. E-mail: izaurafreire@hotmail.com

${ }^{5}$ Ph.D. in Nursing. Professor, Department of Medical-Surgical Nursing, Faculty of Nursing, Universidade de São Paulo. São Paulo, São Paulo, Brazil. E-mail: rafacris@usp.br

${ }^{6}$ Ph.D. in Nursing. Professor, Nursing Department and the Graduate Programs in Nursing and the Health Sciences Center, UFRN. CNPq scholarship. Natal, Rio Grande do Norte, Brazil. E-mail: gilsonvtorres@hotmail.com

7 Ph.D. in Nursing. Professor, Nursing Undergraduate Program and the Graduate Program in Nursing, UFRN. CNPq scholarship. Natal, Rio Grande do Norte, Brazil. E-mail: farnoldo@gmail.com
}

\begin{abstract}
Objective: to analyze the presence and symptoms of stress among artisanal fishers who are victims of spinal cord injury.

Method: this descriptive, cross-sectional and quantitative study was conducted with a non-probabilistic sample of 44 fishers, victims of spinal cord injury on the beaches of the northern coast of Rio Grande do Norte, Brazil. Data were collected using an inventory designed for adults addressing the presence and symptoms of stress, and a form addressing the participants' sociodemographic and clinical variables. Descriptive analysis considered the participants' scores.

Results: all fishers were male, aged $23.87 \pm 20.9$ years old on average; time since the accident that caused the injury was $33.3 \pm 19.31$ years on average; the level of injury most frequently affected was the thoracic spine (41.8\%), of which the main sequel was paraplegia (50.0\%). The findings reveal stress compatible with the exhaustion phase (25.0\%), followed by the resistance phase (13.6\%), with the main symptoms including: insomnia, tachycardia, hypertension, and sexual problems, among others.

Conclusion: the stress identified among the fishers was in the exhaustion phase and physical symptoms predominated. A spinal cord injury impacts the victim's social, occupational and family context, leading to the emergence of stress.

DESCRIPTORS: Psychological stress. Decompression sickness. Spinal cord injuries. Mental Health. Nursing.
\end{abstract}

\section{LESÃO MEDULAR POR MERGULHO E ESTRESSE EM PESCADORES ARTESANAIS}

\section{RESUMO}

Objetivo: analisar a presença e os sintomas de estresse em pescadores artesanais vítimas de lesão medular.

Método: estudo descritivo, seccional e quantitativo, realizado com amostra não probabilística de 44 pescadores vitimados por lesão medular nas praias do litoral norte do Rio Grande do Norte. Os dados foram coletados por meio de aplicação de inventário sobre presença e sintomas de estresse para adultos, conteplando ainda características sociodemográficas e clínicas dos participantes. A etapa de análise considerou o escore e o somatório das respostas obtidas, utilizando-se a estatística descritiva.

Resultados: todos os pescadores eram do sexo masculino, com idade média de 23,87 $\pm 20,9$ anos; tempo médio transcorrido após o acidente de mergulho que desencadeou a lesão de 33,3 $\pm 19,31$ anos; nível medular mais acometido a coluna torácica (41,8\%), tendo como principal sequela a paraplegia $(50,0 \%)$ e o tempo do acidente por mergulho de 33,3 anos. Os achados remetem ao estresse compatível a fase de exaustão $(25,0 \%)$, seguida de resistência $(13,6 \%)$, com destaque para sintomas como insônia, taquicardia, hipertensão, dificuldade sexual, entre outros. Conclusão: constatou-se a presença de estresse entre os pesacadores na fase de exaustão, com predomímio de sintomas físicos. Evidencia-se que a lesão medular por mergulho repercute no contexto social, ocupacional e familiar da vítima, favorecendo o aparecimento de estresse. DESCRITORES: Estresse psicológico. Doença da descompressão. Traumatismos da medula espinal. Saúde mental. Enfermagem. 


\title{
LESION MEDULAR POR BUCEO Y ESTRÉS EN PESCADORES ARTESANALES
}

\begin{abstract}
RESUMEN
Objetivo: analizar la presencia y los síntomas de estrés en pescadores artesanales víctimas de lesión medular.

Método: estudio descriptivo, seccional y cuantitativo, realizado con una muestra no probabilístico de 44 pescadores víctimas de lesión medular en las playas del litoral norte de Rio Grande do Norte. Los datos fueron recolectados por medio de la aplicación de inventario sobre presencia y síntomas de estrés para adultos, contemplando aún características sociodemográficas y clínicas de los participantes. La etapa de análisis consideró el score y la suma de las respuestas obtenidas, utilizando la estadística descriptiva.

Resultados: todos los pescadores eran del sexo masculino, con edad media de 23,87 $\pm 20,9$ años, tiempo medio transcurrido después del accidente de buceo que desencadenó la lesión de 33,3 $\pm 19,31$ años; nivel medular más acometido la columna torácica (41,8\%), teniendo como principal secuela la paraplejia (50,0\%) y el tiempo del accidente por buceo de 33,3 años. Los hallazgos remeten al estrés compatible a la fase de cansancio $(25,0 \%)$, seguida de resistencia $(13,6 \%)$, con destaque para síntomas como insomnio, taquicardia, hipertensión, dificultad sexual, entre otras.

Conclusión: se constató la presencia de estrés entre los pescadores en la fase de cansancio, con predominio de síntomas físicos. Se evidencia que la lesión medular por buceo repercute en el contexto social, ocupacional y familiar de la víctima, favoreciendo la aparición de estrés. DESCRIPTORES: Estrés psicológico. Enfermedad de descompresión. Traumatismos de la médula espinal. Salud mental. Enfermería.
\end{abstract}

\section{INTRODUCTION}

In recent times, stress has become a subject of conversations ranging in format from common sense to scientific discussions. Hence, it has become an object of interest among researchers from various disciplines within the health field, particularly nursing. Stress is frequently conflated with anxiety or fear. In general, it depends on the nature of an event and on one's ability to use resources to adapt to a situation and/or condition in a given amount of time to overcome an external or internal threat. ${ }^{1}$

The Brazilian Public Health System has required a reorganization of health services to meet doctrinal and operational principles linked to the Family Heath Strategy, with an emphasis on health promotion, disease prevention, as well as on the reestablishment of basic concepts of health, disease, and care, aiming to improve quality of life as a consequence of quality care provided to the community. ${ }^{2-3}$ From this perspective, stress permeates all professions and trades and, if we consider professionals in fishery activities along the vast Brazilian coast, we verify that healthcare practitioners are directly involved with the prevention of diseases and health promotion among these workers..$^{3-4}$

Stress is a multifactor event present in others clinical condition as anxiety, coronary arterial disease, mood disorders, neurotransmitter, endocrine, and immune responses, among others, and is also related to one's workplace and requires adaptation. There are also the concepts of stress as a response to the dangers / threats / conflicts found in their environment and what involves the alteration of the basic psychic functions triggering the mental disease. ${ }^{1}$

The environment and ambience should be taken into account in some professional and rec- reational activities because when these activities are performed without proper preventive and protective mechanisms, they pose important risks for the occurrence of Spinal Cord Injuries (SCI). Such activities include artisanal fishery performed in coastal regions. ${ }^{4-5}$ An SCI is characterized as a physical impairment with great personal and social impact, as it produces a severe and incapacitating condition. ${ }^{6}$ Due to its nature, an SCI can be either a temporary or permanent clinical condition of the spinal cord. ${ }^{5-7}$

According to global estimates, from 20 to 40 million individuals per year are affected by SCI, while male young adults compose the segment most frequently affected. ${ }^{8}$ In Brazil, 130,000 individuals present sequelae from this condition. ${ }^{7}$ The main characteristics of SCI are negative motor and sensitive changes and neurovegetative disorders that affect the body below the level of injury. Statistics show that the main causes of SCI are accidents and violence; injuries caused by firearms, car accidents, shallow water diving, and falls, stand out. ${ }^{6,8}$

Artisanal fishers face poor working conditions, excessive physical strain, and without the use of proper safety equipment, they frequently suffer accidents or die, due to causes inherent to diving, such as drowning or shipwreck, or decompression sickness. ${ }^{4}$

Decompression Sickness (DCS) occurs when the diver returns to sea level too quickly. As the individual dives in, the amount of gases dissolved in the blood, mainly oxygen and nitrogen, increases and, if decompression is too abrupt, nitrogen bubbles may form and reach vital organs, leading to mild to severe symptoms, including torpor, weakness and paralysis. ${ }^{6-7}$ Note that the white 
matter of the spinal cord is especially vulnerable to the formation of bubbles and that nitrogen is highly soluble in myelin, mainly affecting the lower thoracic spine, followed by the lumbar, sacral and cervical regions. The most common signs and symptoms of SCI triggered by this type of DCS include lower back pain and paresthesia that may progress to paraplegia or tetraplegia, intestinal and/ or bladder dysfunction. ${ }^{6,9}$

The condition generated by a spinal cord injury significantly compromises one's functional capacity and may become a source of stress. ${ }^{9}$ In addition to social and economic losses, one may lose the ability to work; an individual with an injured spinal cord has to adapt to secondary disorders, such as neurogenic bladder, neuropathic pain, pressure ulcers, autonomic dysreflexia and spasticity, which impose changes in lifestyle and require learning new behaviors, essential to survival and social reinsertion. ${ }^{10-11}$

Considering this context and based on professional experience in teaching and in providing care in the neurology outpatient clinic of the university hospital at the Federal University of Rio Grande do Norte, this investigation is relevant to filling in a gap concerning the symptomatology and stress levels of individuals with spinal cord injuries who are victims of accidents accruing from artisanal fishery. ${ }^{5}$ The biological, psychosocial and spiritual needs of individuals with spinal cord injuries need to be considered from the perspective of humanized care. ${ }^{5}$

Considering scientific interests and those linked to care delivery and the fact that, according to the National Agenda of Priorities of Research in Health, ${ }^{12}$ research addressing individuals with disabilities, and in this case, spinal cord injuries, is not only relevant but also a priority, especially in the nursing field, this study's objective was to analyze the presence and symptoms of stress among artisanal fishers affected by SCI.

\section{METHOD}

This cross-sectional descriptive study with a quantitative approach was conducted in fishery communities on the northern coast of Rio Grande do Norte, Brazil. Data were collected from October 2013 to August 2014 regarding a total of nine beaches: Rio do Fogo, Caiçara do Norte, Zumbi, Barra de Maxaranguape, Pitanguí, Touros, Maracajaú, São Miguel do Gostoso and Pititinga. The fishery communities were selected based on information provided by organizations that support the fishermen, record and make bibliographic contributions, especially the Computerized System of the General Register of Fishery/Amateur Fishermen (SisRGP), which confirmed the high level of diving accidents involving spinal cord injuries caused by decompression sickness in this area.

The study population was composed of all artisanal fishers registered in the SisRGP of the fishery areas who suffered SCI due to diving accidents. The inclusion criteria were: being fishers, victims of SCI due to diving, of either sex, older than 18 years old, who consented to participate in the study. Exclusion criteria were: presenting any disability or communication or cognition problems that hindered data collection. Of the 49 fishermen affected by SCI, five refused to participate in the study, so that the final sample was composed of 44 individuals, a non-probabilistic sample.

An instrument addressing sociodemographic (i.e., sex, age, education, marital status, and family income) and clinical variables (e.g. spinal level affected, sequelae, time since the diving accident) was used, along with the Lipp Inventory Stress Symptoms for Adults (LISS) ${ }^{13}$ LISS is composed of a list of physical and psychological symptoms grouped into three categories, each corresponding to one phase of stress. LISS was validated for the Brazilian context in 1994. It presented high reliability (Alpha coefficient equal to 0.912) and has been used in research and in clinical practice to investigate stress. ${ }^{2-3,14-15}$

LISS presents three phases of stress verification based on symptoms: the first refers to symptomatology experienced in the last 24 hours (Phase I -Alarm); the second phase concerns symptoms from the last week (Phase II - Resistance). Each of the phases has a list of 15 symptoms; and the third phase concerns symptoms experienced in the last three months with a list of 23 symptoms (Phase III - Exhaustion). The cutoff point for phase I is seven or higher; four or higher is the cutoff point of Phase II, while nine or higher is the cutoff point for Phase III. ${ }^{13-14}$

Initially, we contacted the president of the fishery communities to obtain the number and list of those registered in the Ministry of Fisheries and Aquaculture, in the National System of Fishery and Aquaculture Information (SINPESQ) and SisRGP, and also the number of diving accidents. After this step, we scheduled visits to the fishermen's homes where they were invited to participate in the study. Those who agreed and met the inclusion criteria, signed free and informed consent forms. On that occasion, they received clarification about the study 
and when the LISS ${ }^{8}$ and the other form were to be implemented; the researcher read the instrument to illiterate participants.

Data collected through the questionnaires were tabulated using the trial version of the Statistical Package for the Social Sciences (SPSS 20.0). The presence and phase of stress identified were included in this stage, considering the scores obtained by the participants regarding physical and psychological symptoms. Data were analyzed using Microsoft Excel 2010 and SPSS 20.0 with free download. Descriptive analysis was used and the results are presented in Tables, including average and standard deviation.

The study was submitted to and approved by the Institutional Review Board at the Universidade Federal do Rio Grande do Norte (CEP/UFRN) under protocol 431.891 and CAAE 20818913.0.0000.5537, in accordance with the ethical and legal principles established in Resolution 466/2012, Brazilian Council of Health.

There is no conflict of interest, nor ethical or ideological conflicts when using LISS. The same applies to the concepts adopted from psychiatry (CID10 and F.38) and psychopathology. These concepts were used in data collection with no intention to establish a diagnosis, though they indicate conditions and situations that involve aspects of affective disorders, excluding post-traumatic stress disorder because, in most cases, five years had passed since the accident when the study was conducted..$^{1,13,15}$

\section{RESULTS}

The sample was composed of 44 artisanal fishers aged $23.87 \pm 20.9$ years old, on average. Time since the diving accident that caused the injury was $33.3 \pm 19.31$ years on average. The participants' average level of education was completed primary school, at $68.2 \%$ ( \pm 33.12$) ; 29.5 \%$ were illiterate. A total of $34 \%$ of the interviewees were married/in a stable union, while $10 \%$ were single, divorced or widowed; only $4.5 \%$ lived by themselves and received support from friends and neighbors; the remaining lived with some family member. The reported average income was $\mathrm{R} \$ 50.00 \pm 28.9$, considering the interval between minimum and maximum minimum wage in the time span, respectively corresponding to: $\mathrm{R} \$ 674.00$ (2013) and 724.00 (2014). The part of the spine most frequently injured was the thoracic spine $(41.8 \%)$, the main sequel of which was paraplegia (50.0\%), while time since the accident was 33.3 years. Table 1 presents, in detail, the characterization of the sample. Note that most individuals had a paid occupation after their SCI, as self-employed workers in fishery activities or handicrafts $(52.3 \%)$.

Table 1 - Characterization of artisanal fishermen affected by spinal cord injuries. Natal-RN, Brazil, 2014

\begin{tabular}{|c|c|c|c|c|c|}
\hline Characterization of & shermen & $\mathbf{n}$ & $\%$ & $\begin{array}{c}\text { Average } \\
\% \%\end{array}$ & $\begin{array}{l}\text { Standard } \\
\text { deviation }\end{array}$ \\
\hline Sex & Male & 44 & 100.0 & 50 & 7071 \\
\hline sex & Female & 0 & 0.0 & 30 & 70.71 \\
\hline & 18 to 30 years old & 2 & 4,6 & & \\
\hline A r omoun & 31 to 40 years old & 6 & 13,6 & & \\
\hline Age group & 41 to 50 years old & 19 & 43.2 & 20.07 & 20.09 \\
\hline & Above 50 years old & 17 & 38.6 & & \\
\hline & Illiterate & 13 & 29.5 & & \\
\hline Education & Primary/Middle school & 30 & 68.2 & 33.33 & 33.12 \\
\hline & High School & 1 & 2.3 & & \\
\hline Marital ctatuc & Married/Stable union & 34 & 77.3 & 50 & 386 \\
\hline MViarital status & Single/Divorced & 10 & 22.7 & 30 & 00.01 \\
\hline & Has an occupation & 23 & 52.3 & & \\
\hline Current occupation & Retired & 15 & 34.1 & 33.33 & 19.36 \\
\hline & No occupation & 6 & 13.6 & & \\
\hline
\end{tabular}




\begin{tabular}{|c|c|c|c|c|c|}
\hline \multicolumn{2}{|c|}{ Characterization of artisanal fishermen } & \multirow{2}{*}{$\begin{array}{l}\mathbf{n} \\
31\end{array}$} & \multirow{2}{*}{$\begin{array}{c}\% \\
70.5\end{array}$} & \multirow{3}{*}{$\begin{array}{c}\begin{array}{c}\text { Average } \\
\%\end{array} \\
\\
50\end{array}$} & \multirow{3}{*}{$\begin{array}{c}\begin{array}{c}\text { Standard } \\
\text { deviation } \\
\%\end{array} \\
\\
28.99\end{array}$} \\
\hline \multirow{2}{*}{ Family income } & $\begin{array}{l}\text { Up to one times the } \\
\text { minimum wage }\end{array}$ & & & & \\
\hline & $\begin{array}{l}\text { Above one times the } \\
\text { minimum wage }\end{array}$ & 13 & 29.5 & & \\
\hline \multirow{3}{*}{ Spinal level affected } & Thoracic & 23 & 52.3 & & \\
\hline & Lower back & 19 & 43.2 & 33.33 & 25.38 \\
\hline & Cervical & 2 & 4.5 & & \\
\hline \multirow{3}{*}{ Sequelae } & Paraplegia & 22 & 50.0 & & \\
\hline & Paresthesia/pain/spasticity & 20 & 45.6 & 33.36 & 25.10 \\
\hline & Tetraplegia & 2 & 4.5 & & \\
\hline \multirow{3}{*}{ Time since the diving accident } & 1 to 5 years & 6 & 13.7 & & \\
\hline & 6 to 10 years & 15 & 34 & 33.33 & 19.31 \\
\hline & $\geq 10$ years & 23 & 52.3 & & \\
\hline
\end{tabular}

In regard to the presence and phase of stress, most artisanal fishermen presented symptoms that corresponded to the exhaustion phase $(25.0 \%)$, followed by resistance $(13.6 \%)$, while none of the participants were identified as being in the alarm phase (Table 2).

Table 2 - Distribution of fishermen affected by spinal cord injuries according to the presence and phase of stress. Natal-RN, Brazil, 2014

\begin{tabular}{ccccc}
\hline Stress & Phase & n & \% & Total \\
\hline Absent & - & 11 & 25.0 & $11(25.0 \%)$ \\
& Alarm & 0 & 0 & \\
Present & Resistance & 6 & 13.6 & $33(75.0 \%)$ \\
& Exhaustion & 27 & 61,4 & \\
\hline
\end{tabular}

In regard to the stress symptoms experienced by the fishermen in the last week, Table 3 shows that the most frequent were: insomnia (95.5\%), tachycardia (93.2\%), hypertension, and muscle tension both with the same percentage (90.9\%). Data concerning stress symptoms presented in the last month indicate that the most frequent symptoms were: hypertension $(97.7 \%)$, over-thinking $(88.6 \%)$, and decreased libido (88.6\%). The stress symptoms most frequently experienced in the last quarter were: sexual problems and insomnia, both with the same percentage (95.5\%); over-thinking or talking about a single subject and nightmares, with $88.6 \%$ each. Other symptoms include hypertension and a desire to escape from everything, with equal percentages $(86.4 \%)$.

Table 3 - Main symptoms reported in the last week, last month, and quarter, and respective corresponding phases (alarm, resistance or exhaustion). Natal-RN, Brazil, 2014

\begin{tabular}{lcclcc}
\hline Symptom & & & & & \\
\hline Symptoms reported in the last week - Phase I alarm & $\mathbf{n}$ & $\%$ & Symptom & $\mathbf{n}$ & $\%$ \\
\hline Insomnia & 42 & $95.5 \%$ & Temporary diarrhea & 28 & $63.6 \%$ \\
Tachycardia & 41 & $93.2 \%$ & Stomachache & 20 & $45.5 \%$ \\
Hypertension & 40 & $90.9 \%$ & Cold hands and feet & 19 & $43.2 \%$ \\
Muscle tension & 40 & $90.9 \%$ & Excessive sweating & 10 & $22.7 \%$
\end{tabular}




\begin{tabular}{lcclcc}
\hline Symptom & & & & & \\
\hline Symptoms reported in the last week - Phase I alarm & $\mathbf{n}$ & $\%$ & Symptom & $\mathbf{n}$ & $\%$ \\
\hline Clenching teeth & 34 & $77.3 \%$ & Dry mouth & 7 & $15.9 \%$ \\
Change of appetite & 33 & $75.0 \%$ & Wheezing & 4 & $9.1 \%$ \\
Symptoms reported in the last month - Phase II resistance & & & & \\
Hypertension & 43 & $97.7 \%$ & Skin problems & 28 & $63.6 \%$ \\
Over-thinking/over-talking about a single subject & 39 & $88.6 \%$ & Feeling of physical & 26 & $59.1 \%$ \\
Decreased libido & 39 & $88.6 \%$ & Generalized malaise & 25 & $56.8 \%$ \\
Tingling hands & 38 & $86.4 \%$ & Change of appetite & 24 & $54.5 \%$ \\
Memory problems & 38 & $86.4 \%$ & Dizziness & 15 & $34.1 \%$ \\
Self-doubt & 38 & $86.4 \%$ & Ulcers & 12 & $27.3 \%$ \\
Constant fatigue & 34 & $77.3 \%$ & Excessive irritability & 12 & $27.3 \%$ \\
Heightened sensitivity & 34 & $77.3 \%$ & & & \\
Symptoms reported in the last quarter - Phase III exhaustion & & & & \\
Sexual problems & 42 & $95.5 \%$ & Skin problems & 22 & $50.0 \%$ \\
Insomnia & 42 & $95.5 \%$ & Frequent diarrhea & 19 & $43.2 \%$ \\
Over-thinking/over-talking about a single subject & 39 & $88.6 \%$ & Tics & 18 & $40.9 \%$ \\
Nightmares & 39 & $88.6 \%$ & Ulcer & 14 & $31.8 \%$ \\
Hypertension & 38 & $86.4 \%$ & Irritability & 14 & $31.8 \%$ \\
Desire to escape from everything & 38 & $86.4 \%$ & Extreme change of & 12 & $27.3 \%$ \\
Unable to work & 37 & $84.1 \%$ & Lost sense of humor & 10 & $22.7 \%$ \\
Apathy & 34 & $77.3 \%$ & Excessive gas & 5 & $11.4 \%$ \\
Frequent dizziness & 33 & $75.0 \%$ & Excessive nervousness & 7 & $15.9 \%$ \\
Anguish & 33 & $75.0 \%$ & Nausea & 1 & $2.3 \%$ \\
Excessive fatigue & 30 & $68.2 \%$ & & \\
\hline
\end{tabular}

\section{DISCUSSION}

The characterization of fishermen affected by $\mathrm{SCI}$ is in agreement with specific literature reinforcing the profiles of these individuals, usually men of an economically active age, with a low level of education, who were affected by Decompression Sickness. ${ }^{4,10-11}$ Note that there is an absence of women in artisanal fishery, a role and function reserved for men. Women are responsible for preparing and selling fishery products. ${ }^{4}$

SCI is an important public health problem when it occurs during men's productive age because it affects their health, impairs their professional capacity, and disrupts their daily routine, in addition to having social and economic implications. Both family and society are affected, as the condition requires increased expenditures on the part of the state, with healthcare, and requires a long period of reabilitation..$^{8-11}$ In regard to family income, data provided from the beginning to the end of data collection were not precise.

The diving accidents occurred more than 10 years ago during the ban on fishing with decompression devices. After the accident, some sought another source of income, even those who retired due to disabilities. Note that most accidents occurred in the ban period, when fishing was forbidden by law. ${ }^{16-17}$ The fact they broke the law is a problem in their lives. They refuse to report the accident, even though the local community and members of fishery areas are often aware of the accident, because they may not be entitled to retirement, as has happened in some cases in which the accident occurred during the ban period. Occupations mostly revolve around local craftsmanship. ${ }^{17}$

The presence of stress, compatible with the exhaustion phase, was found among the interviewees. No fishermen were in the alarm phase; indicating that most overcame the symptoms as they carried 
on with their lives and treatment, which required new adaptive mechanisms to cope with the stress and SCI. A portion of the participants did not present stress symptoms, leading to the conclusion that the negative image assigned to body integrity after an SCI is not a feeling common to all the participants. Responses are individualized according to one's self-concept and experiences prior to the event. $^{8-9}$ There is also the possibility of collecting varied relationships and experiences developed over the course of life, seeking meaning through body wholeness and an individual image that is constantly changing. ${ }^{9,11}$

The chronic condition(s) caused by the SCI sequelae leads to important social and economic losses that may lead to a feeling of disenchantment with life. These sequelae include impaired working capacity, mobility or ability to take part in leisure activities, requiring one to adapt to situations, such as a loss of autonomy, changes in body image, ambiguous negative feelings, such as fear of permanent disability or social exclusion, which may culminate in stress. ${ }^{1,18-19}$

It is known that most individuals with an SCI remain partially or totally dependent on other people, a situation by itself considered a stress factor. Body segments below the lesion are compromised, in addition to visceral and autonomic changes, and vasomotor, sphincter, sexual and trophic disorders. ${ }^{18}$ These new limitations impede individuals to independently perform many tasks so that balancing dependency and autonomy is a real challenge and often becomes confusing in social relationships established with an individual with SCI. ${ }^{15}$

The stress symptoms presented by the participants, which are mainly physical symptoms, probably reflect emotional aspects affected by the impact of SCI in their lives, which involves hospitalization, the need to interact with the health staff and other patients, the realization that a catastrophic event took place, and culminates in self-image-related conflicts and a consequent compromise of the victim's emotional structure. ${ }^{3}$ These emotional responses vary from person to person according to one's personality, age, emotional maturity, family and sociocultural conditions, as reported by other studies. ${ }^{14,16-17}$

Changes in lifestyle and the need to abandon pleasurable activities should also be taken into account. The new life, characterized by difficulties and limitations, imposed by the injury, coupled with a lack of personal fulfillment that is now hindered by an inability to work in the fishery context, and financial hardships accruing from physical sequelae, represent an important concern for these men. Most are married, the head of a family, and have to survive with a monthly income of up one times the minimum wage, working in occupations with uncertain remuneration, which consequently leads to stress. ${ }^{20-21}$

The consequences of an SCI are not limited to the motor sphere; its effects are extended to practically all vital functions. There are many consequences for the affected individual, his family, friends and for society as a whole, in addition to immeasurable emotional costs. ${ }^{8,20}$ From this perspective, we draw attention to the need to promote mental health and prevent mental and behavioral disorders ${ }^{1}$ that would be consequences of being a victim of physical, emotional and social sequelae that affect individuals with physical disabilities and, naturally, may be associated with depressive symptoms and high levels of anxiety, as these are also associated with sociodemographic conditions. ${ }^{10,18-20}$

During the initial period of adaptation, individuals experience drastic changes in almost every aspect of life. Responses expected in this period of crisis include a brief period of absence of reality and anesthesia, sleep, appetite and digestion disorders, muscle tension, pain, anxiety, depression, reasoning and concentration problems, an attempt to escape from the situation, preoccupation, anger, shame, and guilt $t^{9-11,18}$ These symptoms are experienced by most of the study participants.

It is important to observe and compare the symptoms over time, due to the elements that compose LISS, particularly in Table 3 , in regard to insomnia, hypertension, and sexual problems. Note that the main complaints refer to hypertension and sexual problems, which are followed by other symptoms, each referring to a domain or period under study, and concerning the individuals' ability to adjust or not to their incapacitating conditions, either integrating it into their lives or facing it as a continuum of the SCI condition, the symptomatology of which compromises an indi-

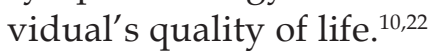

The various risk factors for Systemic Arterial Hypertension (SAH) include sedentariness, stress, inappropriate eating habits, the consumption of alcohol and smoking..$^{18}$ Insomnia emerges as a complaint in various studies addressing the lifestyle and 
quality of life of individuals affected by SCI ${ }^{20}$ Hence, the high percentage of self-reported hypertension and insomnia are expected, considering that most participants were in the exhaustion phase of stress, followed by those in the resistance phase.

The sexual problems experienced by this study's participants concern sexual practice and its frequency, which usually decreases after an $\mathrm{SCI}{ }^{22}$ In regard to the sexual performance of men affected by SCI, most are married and sexually active (some with less than one occurrence of sexual intercourse per week) and are satisfied with their sexual response and spontaneous erection. Some studies report the use of artificial resources to maintain erection, such as a penile ring or oral medication..$^{21-23}$ The occurrence of sexual problems among the participants in this study may be related to the superficial orientation regarding sexuality provided by health providers to the patient and his partner, or even a lack of orientation, which may hinder a couple's sexual adaptation.

Additionally, erectile responses are often insufficient to experience intercourse and may not occur at the desired moment or with sufficient duration. These factors, together with fear of rejection or fear of failure, may lead to a decreased frequency of sexual intercourse and the emergence of problems in one's sexual performance. ${ }^{23}$ Patients using devices for sexual adaptation increase their sexual frequency and become sexually satisfied. ${ }^{21}$ The fishermen affected by SCI caused by diving accidents require humanized and multidisciplinary care because they experience strong emotional, social and physical tensions, which in turn result in stress, from the moment they see themselves as physically disabled..$^{8,11}$

There is a need to provide information, minimize prejudice and conflicts, as a way to encourage and support patients affected by SCI, so that they may resume their sexual and social roles with a positive attitude, aiming to improve their quality of life based on therapy that is able to decrease stressors and promote their rehabilitation process. ${ }^{20}$

Note that there are limitations and a level of difficulty when addressing individuals affected by SCI, especially artisanal fishermen. The reason is that these individuals violate the fishing ban (called Defeso [forbidden]), a time when fishery activities are suspended for species preservation. During this time, those fishermen registered in the fishery area receive a salary benefit ${ }^{7,17}$ and those who suffer accidents under this condition are not entitled to accident insurance. Most of the artisanal work takes place in the economy's informal sector, so that these workers exclusively depend on governmental assistance and require appropriate public healthcare.

\section{CONCLUSION}

Most fishermen who suffered a diving accident during artisanal fishing present stress that corresponds to the exhaustion phase, predominantly physical symptoms such as insomnia, hypertension, decreased libido and/or sexual problems. These symptoms reflect the impact and direct consequences of SCIs on one's social, occupational, and family context, affecting their sexuality, work ability, and independence, among other aspects, which favors the emergence of stress.

This study's findings confirm the relevance and importance of studies of this nature, especially because this study was conducted in a Brazilian region with extensive coastal and fishery areas, so it contributes to the debate concerning SCI and the consequences of decompression sickness among artisanal fishermen, especially emotional overload, with a view to direct health care practices and orient multidisciplinary teams to broaden and ensure access to and quality of care delivered in the primary health care network. More investments are needed to implement continuing education among healthcare practitioners, especially nursing professionals, to promote technical, ethical, and humanized strategies that are able to minimize stress-related factors, such as attentive listening, the appropriate reception of patients, and humanized environments, treatment and rehabilitation.

\section{REFERENCES}

1. Sadock BJ, Sadock VA. Compêndio de psiquiatria: ciência do comportamento e psiquiatria clínica. $9^{\mathrm{a}} \mathrm{ed}$. Porto Alegre (RS): Artmed; 2011.

2. Rosario CAR, Lopes AN, Pereira FFA, Costa FM. Avaliação do estresse entre enfermeiros que atuam na estratégia Saúde da família de Montes Claros, MG. Rev Norte Mineira de Enferm. 2015; 4(1):3-14.

3. Assis MR, Caraúna H, Karine D. Análise do estresse ocupacional em profissionais da saúde. Conexões PSI. 2015; 3(1):62-71.

4. Saldanha MCW, Oliveira LP, Celestino JEM, Veloso ITBM. Construção de demandas e tecnologia social: 
aplicação na atividade jangadeira. Extensão e Sociedade [Internet]. 2010 [cited 2016 Jul 30]; 2(1):121. Available from: http://www.periodicos.ufrn.br/ extensaoesociedade/article/view/869/802

5. Schoeller SD, Bitencourt RN, Leopardi MT, Pires DP, Zanini MTB. Changes in the life of people with acquired spinal cord injury. Rev Eletr Enferm [Internet]. 2012 [cited 2016 Jul 30]; 14(1):95-103. Available from: https://www.fen.ufg.br/fen revista/v14/n1/pdf/v14n1a11.pdf

6. Morais DF, Spotti AR, Cohen MI, Mussi SE, Melo Neto JS, Tognola WA. Epidemiological profile of patients suffering from cord spinal injury treated in tertiary hospital. Coluna/Columna [Internet]. 2013 [cited 2016 Jul 30]; 12(2):149-52. Available from: http://www. scielo.br/pdf/coluna/v12n2/12.pdf

7. Ministério da Saúde (BR). Secretaria de Atenção à Saúde. Departamento de Ações Programáticas Estratégicas: Diretrizes de Atenção à Pessoa com Lesão Medular. Brasília (DF): Ministério da Saúde; 2013.

8. Cavalcante ES, Miranda FAN, Gomes ATL, Freire ILS, Faro ACM. Men with spinal cord injury in rehabilitation: a contextual analysis. Rev Enferm UFPE on line [Internet]. 2015 [cited 2016 Jul 30]; 9(10):9601-7. Available from: http://www.revista. ufpe.br/revistaenfermagem/index.php/revista/ article/view/7824/pdf_8756

9. Santinoni R, Araujo TCCF. Enfrentamento e lesão medular: um estudo de corte transversal com pacientes em reabilitação. Com Ciências Saúde [Internet]. 2011 [cited 2016 Jul 30]; 22(3):21120. Available from: http://bvsms.saude.gov. br/bvs/periodicos/revista_ESCS_v22_n3_a03_ enfrentamento_lesao_medular.pdf

10. França ISX, Enders BC, Coura AS, Cruz GKP, Aragão JS, Oliveira DRC. Lifestyle and health conditions of adults with spinal cord injury. Invest Educ Enferm [Internet]. 2014 [cited 2016 Jul 30]; 32(2):244-51. Available from: http:/ / www.scielo.org.co/pdf/iee/ v32n2/v32n2a07.pdf

11. Cerezetti CRN, Nunes GR, Cordeiro DRCL, Tedesco S. Lesão Medular Traumática e estratégias de enfrentamento: revisão crítica. Mundo Saúde [Internet]. 2012 [cited 2016 Jul 30]; 36(2):318-26. Available from: http:/ /www.saocamilo-sp.br/pdf/ mundo_saude/93/art07.pdf

12. Ministério da Saúde (BR). Secretaria de Ciência, Tecnologia e Insumos Estratégicos. Departamento de Ciência e Tecnologia. Agenda nacional de prioridades de pesquisa em saúde [Internet]. $2^{\mathrm{a}}$ ed. Brasília (DF):
Ministério da Saúde; 2011 [cited 2016 Oct 24]. Available from: http:/ / bvsms.saude.gov.br/bvs/publicacoes/ agenda_nacional_prioridades_2ed_3imp.pdf

13. Lipp MEN. Manual do Inventário de Sintomas de Stress para adultos de Lipp. São Paulo: Casa do Psicólogo; 2014.

14. Ramiro FS, Lombardi Júnior I, Silva RCB, Montesano FT, Oliveira NRC, Diniz REAS, et al. Investigation of stress, anxiety and depression in women with fibromyalgia: a comparative study. Rev Bras Reumatol [Internet]. 2014 [cited 2016 Jul 30]; 54(1):27-32. Available from: http://www.scielo.br/pdf/rbr/ v54n1/en_0482-5004-rbr-54-01-0027.pdf

15. Suarez R. Teste de Lipp - Teste de Lipp ISS. In ventário Sintomas de Stress [Internet]. 2014 [cited 2016 Oct 23] Available from: http://www. forms. med.br $/$ index.pl? C $=A \& V=66466 F 726 D$ 49443D38343731267072696E743D31266654656D 706C61746549443D3136343536266163743D73686F 7754656D706C617465

16. Ministério da Saúde (BR). Lei no 11.699. Dispõe sobre as Colônias, Federações e Confederação Nacional dos Pescadores, regulamentando o parágrafo único do art. $8^{\circ}$ da Constituição Federal e revoga dispositivo do decreto-lei $\mathrm{n}^{\circ} 221$, de 28 de fevereiro de 1967 [Internet]. Ministério da Saúde; 2008. [cited 2016 Jul 30]. Available from: http://www.planalto.gov.br/ ccivil_03/_ato2007-2010/2008/lei/111699.htm

17. Cavalcante ES, Izaura LSF, Danta BAS, Cavalcante CAA, Gomes ATL, Miranda FAN. ishermen victims of decompression sickness: study in a naval hospital. Rev Enferm UFPE on line [Internet]. 2015 [cited 2016 Oct 26]: 9(10):9520-7. Available from: http://www. revista.ufpe.br/revistaenfermagem/index.php/ revista/article/viewFile/7891/pdf_8713

18. Teixeira AR, Alves JB, Santos A, Gestal-Otero J. Traumatic spinal cord injury: the impact of sociodemographic variables on the adjustment and mental health of subjects affected. Psicol Saúde Doenças [Internet]. 2014 [cited 2016 Jul 30]; 15(1):11121. Available from: http:/ / www.scielo.mec.pt/pdf/ psd/v15n1/v15n1a10.pdf

19. Magalhães SR, Carvalho ZMF, Andrade LM, Pinheiro $A K B$, Studart RMB. Influence of spirituality, religion and beliefs in the quality of life of people with spinal cord injury. Texto Contexto Enferm [Internet]. 2015 [cited 2016 Ago 17]; 24(3):792-800. Available from: http:/ / www.scielo.br/pdf/tce/v24n3/0104-0707tce-2015000620014.pdf

20. Fechio MB, Pacheco KMB, Kaihami HN, Alves VLR. The repercussions of a spinal cord injury over 
the individual's identity. Acta Fisiátrica [internet]. 2009 [cited 2016 Jul 30]; 16(1):38-42. Available from: http://www.actafisiatrica.org.br/detalhe_artigo. asp?id=120\#

21. Landeiro MJL, Martins TV, Peres HHC. Nurses' perception on the difficulties and information needs of family members caring for a dependent person. Texto Contexto Enferm [Internet]. 2016 [cited 2016 Ago 17]; 25(1):e0430015. Available from: http://www.scielo. br/pdf/tce/v25n1/0104-0707-tce-25-01-0430015.pdf

22. Torrecilha LA, Costa BT, Lima FB, Santos SMS, Souza
RB. Profile of sexuality in men with spinal cord injury. Fisioter Mov (Curitiba) [Internet]. 2014 [cited 2016 Jul 30]; 27(1):39-48. Available from: http:/ / www.scielo. $\mathrm{br} / \mathrm{pdf} / \mathrm{fm} / \mathrm{v} 27 \mathrm{n} 1 / 0103-5150-\mathrm{fm}-27-01-0039 . \mathrm{pdf}$

23. Costa BT, Torrecilha LA, Paloco AS, Spricigo JMVA, Souza RB, Santos SMS. Sexual profile and adaptations of men after spinal cord injury. Acta Fisiatrica [internet]. 2014 [cited 2016 Jul 30]; 21(4):177-82. Available from: http://www.actafisiatrica.org.br/ detalhe_artigo.asp?id=562 